\title{
Indirubin-3-monoxime Prevents Tumorigenesis in Breast Cancer through Inhibition of JNK1 Activity
}

\author{
Mi-Yeon Kim ${ }^{1, \$, *}$, Eun-Hye Jo ${ }^{1,, *}$, Yong-Chul Kim ${ }^{2, * *}$ and Hee-Sae Park ${ }^{1, ;, * *}$ \\ ${ }^{I}$ School of Biological Sciences and Technology, Chonnam National University, Gwangju 61186, Korea \\ ${ }^{2}$ School of Life Sciences, Gwangju Institute of Science \& Technology, Gwangju 61186, Korea
}

c-Jun N-terminal kinases (JNKs) have a Janus face, regulating both cell apoptosis and survival. The present study focused on understanding the function of JNK in tumor development and the chemoresistance underlying JNK-mediated cancer cell survival. We identified an inhibitor of JNK1, an important regulator of cancer cell survival. Kinase assay data showed that JNK1-dependent c-Jun phosphorylation was inhibited by indirubin derivatives. In particular, indirubin3-monoxime (I3M) directly inhibited the phosphorylation of c-Jun in vitro, with a half inhibition dose $\left(\mathrm{IC}_{50}\right)$ of $10 \mathrm{nM}$. I3M had a significant inhibitory effect on JNK1 activity. Furthermore, we carried out assays to determine the viability, migration, and proliferation of breast cancer cells. Our results demonstrated that cell growth, scratched wound healing, and colony forming abilities were inhibited by the JNK inhibitor SP600125 and I3M. The combination of SP600125 and I3M significantly decreased cancer cell proliferation, compared with either SP600125 or I3M alone. Our studies may provide further support for JNK1-targeting cancer therapy using the indirubin derivative I3M in breast cancer.

Key Words: Cancer proliferation, Indirubin-3-monoxime, c-Jun N-terminal kinase, Phosphorylation inhibition, Triple negative breast cancer, Tumorigenesis

\section{INTRODUCTION}

c-Jun N-terminal protein kinases (JNKs) are involved in various physiological processes (Mehan et al., 2011). JNKs are a cellular response activated through environmental stresses such as osmotic stress, UV irradiation, metabolic inhibitors, and heat shock (Cargnello and Roux, 2011). The JNK signaling cascade performs a function in a important of physiological processes, regarding cell survival, apoptosis, cell proliferation, and gene expression (Lin and Dibling, 2002; Zhao et al., 2015), and responds to cytokines (Verrecchia et al., 2003) and growth factors. The JNK kinase family comprise JNK1-3; of these, JNK1, 2 are ubiquitously expressed, whereas JNK3 expression is limited to the testis, brain, and heart (Bogoyevitch and Kobe, 2006).

c-Jun activation is triggered by the JNK-induced phosphorylation of serine 63 and 73. It composes homo- or heterodimers with the ATF (activating transcription factor), MAF (musculoaponeurotic fibrosarcoma), and FOS to comprise the transcription factor activator protein-1 (AP-1). The JNK signaling pathway connected with neuronal cell death has been widely studied (Guan et al., 2005; Hui et al., 2005). Recent evidence indicates that JNK is connected

Received: August 25, 2021 / Accepted: September 14, 2021

*Post-Doctor, ${ }^{* *}$ Professor.

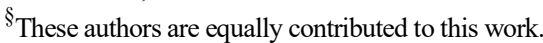

${ }^{\dagger}$ Corresponding author: Hee-Sae Park. School of Biological Sciences and Technology, Chonnam National University, Yongbong-dong, Buk-ku, Gwangju 61186, Korea.

Tel: +82-62-530-0021, Fax: +82-62-530-2199, e-mail: proteome@jnu.ac.kr

(C) The Korean Society for Biomedical Laboratory Sciences. All rights reserved.

(C) This is an Open Access article distributed under the terms of the Creative Commons Attribution Non-Commercial License (http://creativecommons.org/licenses/by-nc/3.0/) which permits unrestricted non-commercial use, distribution, and reproduction in any medium, provided the original work is properly cited. 
with cancer cell survival (Park et al., 2019), and that the crosstalk between JNK and other pathways is important in cancer development. JNK activation is associated with a poor prognosis in breast cancer and is important for tumor initiation and metastasis in mouse models of breast cancer (Insua-Rodriguez et al., 2018).

Triple negative breast cancers (TNBC) have a poor clinical effect contrasted to other breast cancer subtypes. TNBCs do not have the typical human epidermal growth factor receptor 2 (EGFR2), progesterone receptor (PR), and estrogen receptor (ER) that are commonly found in breast cancer (Lehmann et al., 2011). Several TNBCs overexpress human EGFR, which correlates with poor prognosis (Nielsen et al., 2004). Previous reports determined that as amount of phospho-JNK expression increase, tumor node metastasis (TNM) stage also increase and that phospho-JNK expression is correlated with positivity expression for $\mathrm{CK} 5 / 6$, basallike, EGFR, and triple-negative phenotype of breast cancer (Wang et al., 2010). Based on these findings, inhibition of JNK activity might be a key target for cancer therapy. Several JNK pathway inhibitors have been developed; however, problems with substrate specificity and side effects remain.

Indirubin was known as an active component of Danggui Longhui Wan, a Chinese herb used in the treatment, in the therapy of a variety of illness, as well as chronic myelocytic leukemia (Xiao et al., 2002). Indirubin and its derivatives have been verified as distinguished inhibitors of fibroblast growth factor receptor 1 (FGFR1), glycogen synthase kinase$3 \beta$ (GSK-3 $\beta$ ), JNK, cyclin-dependent kinases (CDKs), Src kinase, muscle glycogen phosphorylase $\beta$, and the aryl hydrocarbon receptor (Bain et al., 2003; Zhen et al., 2007). Indirubin inhibits CDK kinase activity by competing with ATP which binding to the catalytic site of CDK kinase (Nam et al., 2005). Indirubin and its derivatives have been inhibited the growth of cultured cell types through a arrest of the G1/S or G2/M phase of the cell cycle (Hoessel et al., 1999; Marko et al., 2001). Compared with its derivatives, indirubin itself was known a significant gastrointestinal toxicity, low absorption rate, and poor solubility and indirubin-3-monoxime (I3M) was known reduced toxicity and better pharmacological properties (Lo and Chang, 2013). I3M has also been reported to induce mitochondrial dysfunction and antipro- liferative effects in vascular smooth muscle cells and trigger cell cycle arrest and growth inhibition in human neuroblastoma cells (Bain et al., 2003; Schwaiberger et al., 2010; Liao and Leung, 2013). In conclusion, I3M is one of the most important compound for the treatment of cancer.

In this study, we identified that $\mathrm{I} 3 \mathrm{M}$ can regulate the JNK1 signaling pathway. Conclusionally, our studies indicate that $\mathrm{I} 3 \mathrm{M}$ acts as a negative regulator of the JNK1 signaling pathway, and it may serve as a latent therapeutic agent for the cure of breast cancer.

\section{MATERIALS AND METHODS}

\section{Cell culture plasmids and transfection}

Human embryonic kidney 293 (HEK293) and MDA-MB 231 cell lines were cultured at $37^{\circ} \mathrm{C}$ in Dulbecco's modified Eagle's medium (DMEM, Gibco, USA), supplemented with $10 \%$ fetal bovine serum (FBS, Gibco, USA) and 1\% penicillin/streptomycin (Gibco, USA), in a humidified incubator with an atmosphere of $95 \%$ air and $5 \% \mathrm{CO}_{2}$. A full-length $J N K 1$ gene was constructed via PCR and inserted into the mammalian expression vector pcDNA3. For plasmid DNA transfection, cells were plated at a density of $50 \sim 60 \%$ confluence, grown overnight, and transfected with appropriate expression vectors in the presence of the indicated combinations of plasmid DNA ( $2 \mu \mathrm{g}$ per well), using the Lipofectamine ${ }^{\circledR} 2000$ reagent (Invitrogen, USA).

\section{Kinase assay}

Cultured cells were harvested and lysed in buffer A, containing $50 \mathrm{mM}$ Tris- $\mathrm{HCl}$ (pH 7.5, LPS solusion, Korea), $150 \mathrm{mM} \mathrm{NaCl}, 1 \mathrm{mM}$ phenylmethylsulfonyl fluoride (PMSF, Sigma-Aldrich, USA), $2 \mu \mathrm{g} / \mathrm{mL}$ of leupeptin (Sigma-Aldrich, USA), $2 \mu \mathrm{g} / \mathrm{mL}$ of aprotinin (Sigma-Aldrich, USA), $25 \mathrm{mM}$ glycerophosphate (Sigma-Aldrich, USA), $0.1 \mathrm{mM}$ sodium orthovanadate (Sigma-Aldrich, USA), $1 \mathrm{mM}$ sodium fluoride (Sigma-Aldrich, USA), 1\% NP-40 (VWR Life Science, USA), $0.5 \%$ deoxycholate (Sigma-Aldrich, USA), and $0.1 \%$ SDS (Sigma-Aldrich, USA), for $30 \mathrm{~min}$ at $4{ }^{\circ} \mathrm{C}$. The cell lysates were then subjected to centrifugation at $12,000 \times g$ for $20 \mathrm{~min}$ at $4{ }^{\circ} \mathrm{C}$. The soluble fraction was incubated for $3 \mathrm{~h}$ with the appropriate antibodies against the indicated protein 
kinase at $4^{\circ} \mathrm{C}$. The immunocomplexes were then coupled to protein A-agarose during an additional hour of incubation at $4{ }^{\circ} \mathrm{C}$, after which they were pelleted via centrifugation. The immunopellets were rinsed thrice with lysis buffer and then twice with $20 \mathrm{mM}$ HEPES (pH 7.4, Sigma-Aldrich, USA). The immunocomplex kinase assays were conducted by incubating the immunopellets for $30 \mathrm{~min}$ at $30^{\circ} \mathrm{C}$, with $2 \mu \mathrm{g}$ of GST-c-Jun as substrate protein in $20 \mu \mathrm{L}$ of reaction buffer, which contained $0.2 \mathrm{mM}$ sodium orthovanadate (Sigma-Aldrich, USA), $10 \mathrm{mM} \mathrm{MgCl}$ (VWR Life Science, USA), $2 \mu \mathrm{Ci}\left[{ }^{32} \mathrm{P}\right]$ ATP (PerkinElmer, USA), and $20 \mathrm{mM}$ HEPES (pH 7.4, Sigma-Aldrich, USA). The phosphorylated substrates were separated by SDS-PAGE and quantified using the Fuji FLA7000 phosphoimager (Fuji, Japan). The GST fusion proteins that were used as substrates were expressed in E. coli using pGEX-4T (Pharmacia, USA), and purified using glutathione-Sepharose (GE Healthcare Bio-Sciences AB, USA), as described previously. The protein concentrations were determined using the Bradford method.

\section{Synthesis of indirubin and indirubin derivatives}

Indirubin derivatives were synthesized and characterized via high-resolution mass spectrometry and ${ }^{1} \mathrm{H}$ NMR to verify their identity and purity (Moon et al., 2006). In brief, $176 \mathrm{mg}(1 \mathrm{mmol})$ of indoxyl acetate and $1 \mathrm{mmol}$ of isatin analogue in $5 \mathrm{~mL}$ of methanol were added to $256 \mathrm{mg}$ ( 2.5 mmol) of $\mathrm{Na}_{2} \mathrm{CO}_{3}$ under a nitrogen atmosphere, and the mixture was stirred for $2 \sim 3 \mathrm{~h}$ at room temperature $\left(25^{\circ} \mathrm{C}\right)$. The dark violet precipitate was filtered and washed twice with methanol and several times with cold water, and dried under reduced pressure (yield 50 60\%). Subsequently, 6 mmol of hydroxylamine hydrochloride was added to a solution of indirubin analogues $(1 \mathrm{mmol})$ in $10 \mathrm{~mL}$ of pyridine and the mixture was refluxed for $2 \sim 3 \mathrm{~h}$ at $120^{\circ} \mathrm{C}$. After cooling, the product was neutralized with $1 \mathrm{~N} \mathrm{HCl}$ and the precipitate was filtered and washed with water (Lee et al., 2008).

\section{MTT assay}

MTT (3-(4, 5-dimethylthiazol-2-yl)-2,5diphenyltetrazolium bromide, Sigma-Aldrich, USA) was prepared as a stock solution of $5 \mathrm{mg} / \mathrm{mL}$ in phosphate-buffered saline (PBS, $\mathrm{pH}$
7.2) and filtered. After the end of reaction time (60 h), $20 \mu \mathrm{L}$ of MTT solution was added to each well. After incubation for $4 \mathrm{~h}$ at $37^{\circ} \mathrm{C}$, the medium with the MTT reagent was removed and $150 \mu \mathrm{L}$ of DMSO was added to dissolve the formazan crystals. The 96 -well plate was read by an enzymelinked immunosorbent assay (ELISA) reader at $570 \mathrm{~nm}$ for absorbance density values to determine the cell viability. All measurements were carried out in triplicate. Percentage of viable cells was calculated using the following formula: $(\%)=[100 \times($ sample abs $) /($ control abs $)]$.

\section{Wound healing assay and colony forming assay}

MDA-MB 231 cells were cultured to confluence in 12well plates, then scratched with a P200 micropipette tip. The wound healing area was monitored at $0,24,32$, and $48 \mathrm{~h}$ using a microscope. Wound healing area measurements were performed using the ImageJ software. For the colony forming assay, MDA-MB 231 cells were seeded at 100 cells per $24-w e l l$ plate, then incubated at $37^{\circ} \mathrm{C}$ and $5 \%$ $\mathrm{CO}_{2}$ for $10 \sim 12$ days until colony formation was observed. The medium was replaced every 3 days. After incubation, colonies were fixed with $100 \%$ methanol and stained with $0.05 \%$ crystal violet for $20 \mathrm{~min}$ at room temperature. Colony counting and measurements were performed using the ImageJ software.

\section{Statistical analysis}

All experiments were performed at least three times. Data are presented as mean \pm standard deviation (SD) values. Student's $t$-test (two-tailed) was used to analyze differences between treated and untreated groups. Data were analyzed using the Sigma-Plot software program. $P$-values $<0.05$ were considered statistically significant.

\section{RESULTS}

\section{I3M negatively regulates JNK1 kinase activity}

Previous studies have reported that I3M directly inhibits the activities of recombinant active JNK1, JNK2, and JNK3 (Xie et al., 2004). To verify the possible function of indirubin derivatives in regulation of the JNK1 signaling pathway, an in vitro kinase assay was performed. We used a 


\begin{tabular}{|c|c|c|c|c|c|c|c|c|c|c|c|c|c|c|c|c|c|}
\hline \# & ST & MW & $\#$ & ST & MW & $\#$ & ST & MW & $\#$ & ST & MW & $\#$ & ST & MW & \# & ST & MW \\
\hline 1 & & $\begin{array}{l}262 . \\
2703\end{array}$ & 11 & & $\begin{array}{l}295 . \\
2754\end{array}$ & 21 & & $\begin{array}{l}386 . \\
1639\end{array}$ & 31 & & $\begin{array}{l}402 . \\
4347\end{array}$ & 41 & & $\begin{array}{l}446 . \\
4695\end{array}$ & 51 & t & $\begin{array}{l}426 . \\
4355\end{array}$ \\
\hline & & $\begin{array}{c}277 . \\
28497\end{array}$ & 12 & & $\begin{array}{c}291 . \\
31206\end{array}$ & 22 & & $\begin{array}{l}401 . \\
1785\end{array}$ & 32 & & $\begin{array}{l}390 . \\
4456\end{array}$ & 42 & & $\begin{array}{l}441 . \\
4065\end{array}$ & 52 & & $\begin{array}{l}422 . \\
4472\end{array}$ \\
\hline 3 & & $\begin{array}{c}346 . \\
26808\end{array}$ & 13 & & $\begin{array}{c}311 . \\
73\end{array}$ & 23 & & $\begin{array}{l}276 . \\
2974\end{array}$ & 33 & & $\begin{array}{l}430 \\
854\end{array}$ & 43 & & $\begin{array}{l}410 . \\
4361\end{array}$ & 53 & & $\begin{array}{l}486 . \\
404\end{array}$ \\
\hline 4 & & $\begin{array}{c}361 . \\
28275\end{array}$ & 14 & & $\begin{array}{l}403 . \\
1814\end{array}$ & 24 & & $\begin{array}{l}296 . \\
7153\end{array}$ & 34 & & $\begin{array}{l}386 . \\
3701\end{array}$ & 44 & & $\begin{array}{l}464 . \\
4074\end{array}$ & 54 & & $\begin{array}{l}441 . \\
4065\end{array}$ \\
\hline & & $\begin{array}{c}276 . \\
30024\end{array}$ & 15 & & $\begin{array}{c}305 . \\
33915\end{array}$ & 25 & & $\begin{array}{l}388 . \\
1667\end{array}$ & 35 & & $\begin{array}{l}430 \\
854\end{array}$ & 45 & & $\begin{array}{l}376 . \\
4186\end{array}$ & 55 & & $\begin{array}{l}373 . \\
2939\end{array}$ \\
\hline & & $\begin{array}{c}304 . \\
30794\end{array}$ & 16 & & $\begin{array}{c}325 . \\
75709\end{array}$ & 26 & & $\begin{array}{l}290 . \\
3245\end{array}$ & 36 & & $\begin{array}{l}360 . \\
3755\end{array}$ & 46 & of & $\begin{array}{l}460 . \\
8805\end{array}$ & 56 & & $\begin{array}{l}350 \\
3367\end{array}$ \\
\hline 7 & & $\begin{array}{c}388 . \\
30572\end{array}$ & 17 & & $\begin{array}{l}356 . \\
181\end{array}$ & 27 & & $\begin{array}{l}310 . \\
7424\end{array}$ & 37 & & $\begin{array}{l}402 . \\
4568\end{array}$ & 47 & & $\begin{array}{l}460 . \\
8805\end{array}$ & 57 & & $\begin{array}{l}424 . \\
4632\end{array}$ \\
\hline 8 & & $\begin{array}{c}309 . \\
28377\end{array}$ & 18 & & $\begin{array}{c}367 . \\
33824\end{array}$ & 28 & & $\begin{array}{l}277 \\
285\end{array}$ & 38 & os & $\begin{array}{l}374 . \\
4026\end{array}$ & 48 & o & $\begin{array}{c}362 . \\
3915\end{array}$ & 58 & & $\begin{array}{l}440 \\
4626\end{array}$ \\
\hline 9 & & $\begin{array}{c}280 . \\
26073\end{array}$ & 19 & & $\begin{array}{c}357 . \\
34717\end{array}$ & 29 & & $\begin{array}{l}376 . \\
4186\end{array}$ & 39 & $\infty$ & $\begin{array}{l}414 . \\
3994\end{array}$ & 49 & of & $\begin{array}{l}486 . \\
5348\end{array}$ & & & \\
\hline & & $\begin{array}{c}324 . \\
29844\end{array}$ & 20 & & $\begin{array}{c}341 . \\
16633\end{array}$ & 30 & & $\begin{array}{c}362 . \\
3915\end{array}$ & 40 & of & $\begin{array}{l}414 . \\
3994\end{array}$ & 50 & (2) & $\begin{array}{l}412 . \\
2457\end{array}$ & & & \\
\hline
\end{tabular}

Fig. 1. Chemical structure of indirubin derivatives.

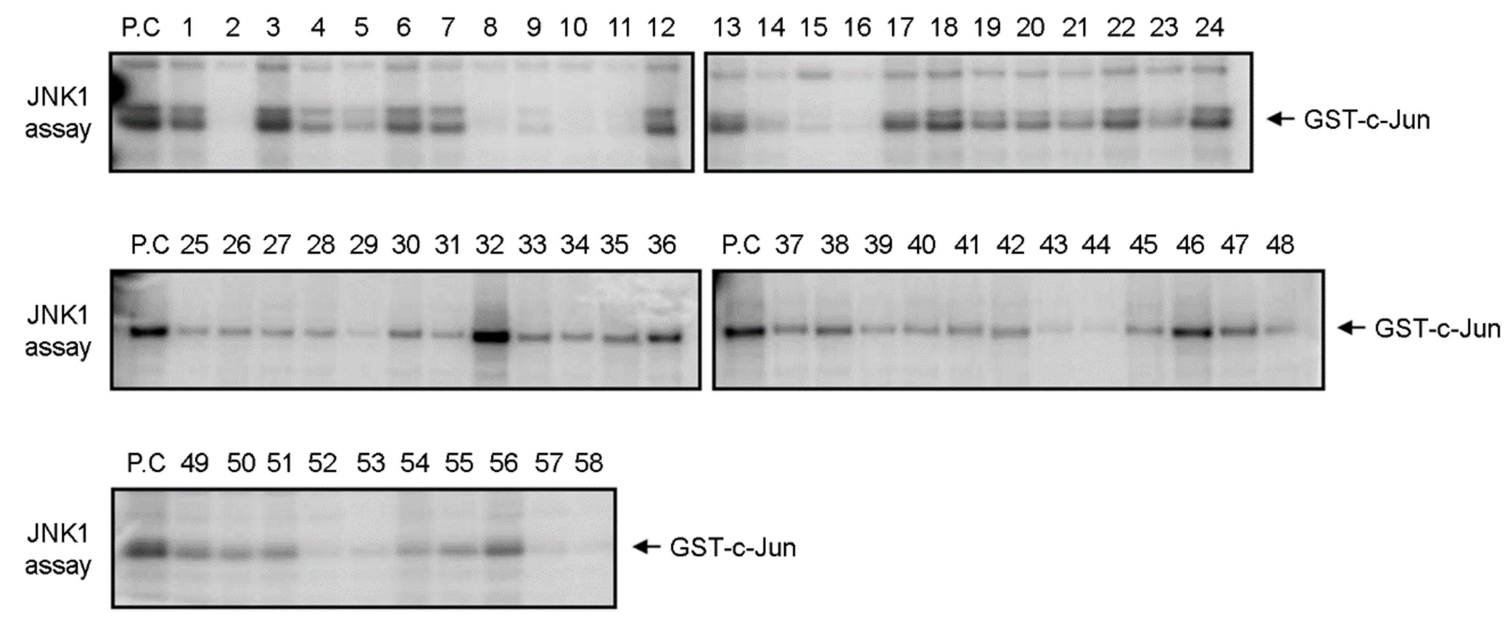

Fig. 2. Indirubin derivatives regulate JNK1 activity. After transiently transfected with plasmids expressing pcDNA3-HA-JNK1 at HEK 293 cells and then treated for $4 \mathrm{~h}$ with indirubin derivatives. The cells were lysed and then immunoprecipitated using anti-HA antibody, after $48 \mathrm{~h}$ of transfection. The immunopellets were incubated with purified GST-c-Jun, then assayed for JNK1 activity.

Fuji FLA7000 phosphorimager to quantify the phosphorylation of c-Jun. Fig. 1 shows the chemical structure of indirubin compound. As shown in Fig. 2, indirubin compound markedly inhibited the in vitro phosphorylation of c-Jun by JNK1. Among the indirubin compound, I3M significantly blocked JNK1 kinase activity. To confirm the
JNK1 inhibitory effect of I3M, we was performed an in vitro kinase assay, with JNK1 as the kinase and GST-c-Jun as the substrate, in a concentration-dependent manner (Fig. 3B). I3M markedly inhibited the in vitro phosphorylation of c-Jun by JNK1. These results suggest that I3M blocks JNK1 activity directly. 
A

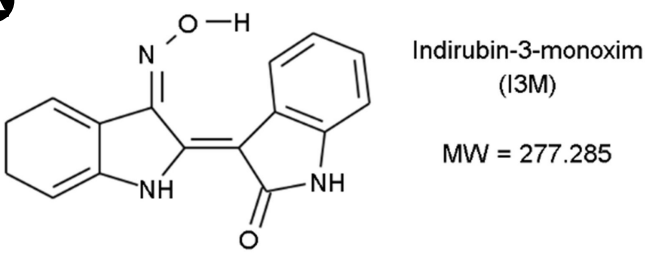

B

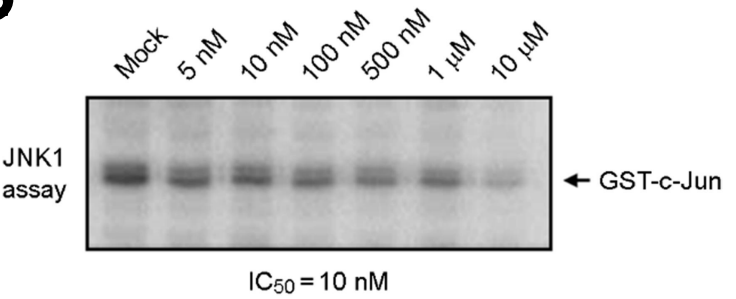

Fig. 3. I3M suppresses JNK1 activity. (A) Chemical structure of I3M. (B) After transiently transfected with plasmids expressing pcDNA3-HA-JNK1 at HEK 293 cells and then treated with various concentrations $(5,10,100,500,10,000$, and $100,000 \mathrm{nM})$ of $\mathrm{I} 3 \mathrm{M}$ for $4 \mathrm{~h}$. The cells were lysed and then immunoprecipitated using anti-HA antibody, after $48 \mathrm{~h}$ of transfection. The immunopellets were incubated with purified GST-c-Jun, then assayed for JNK1 activity.

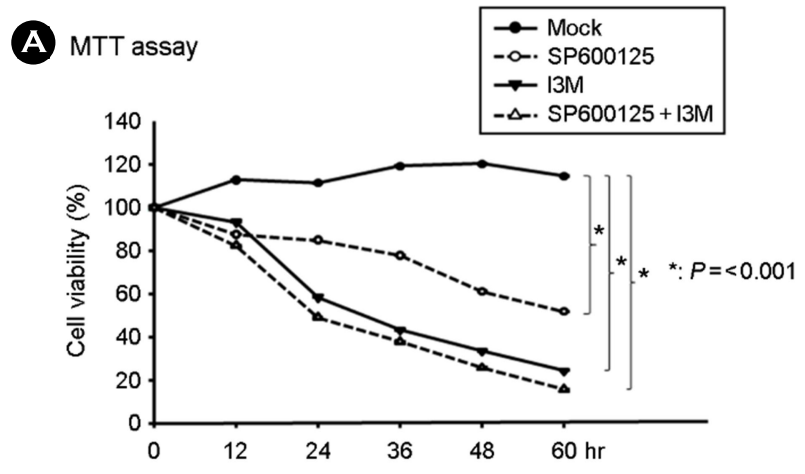

C

Colony forming assay
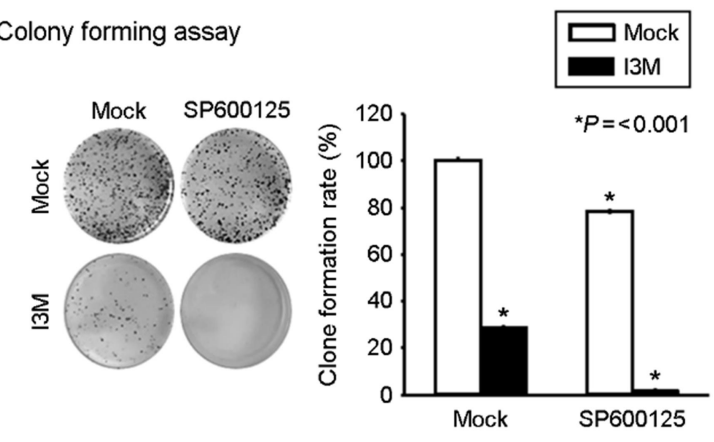
SP600125. Cell viability was assessed based on the MTT assay. The DMSO-treated MDA-MB-231 cells grew steadily over $60 \mathrm{~h}$, while treatment with either SP600125 or I3M inhibited the viability of cells (Fig. 4A). SP600125 and I3M synergized to cause apoptosis. To confirm the effect of cell proliferation by I3M, we was performed a scratched wound healing and colony forming analyses. We confirmed that the cellular proliferation delay caused by I3M could be increased by the JNK inhibitor SP600125 (Fig. 4B, C). As shown in

B Wound healing assay
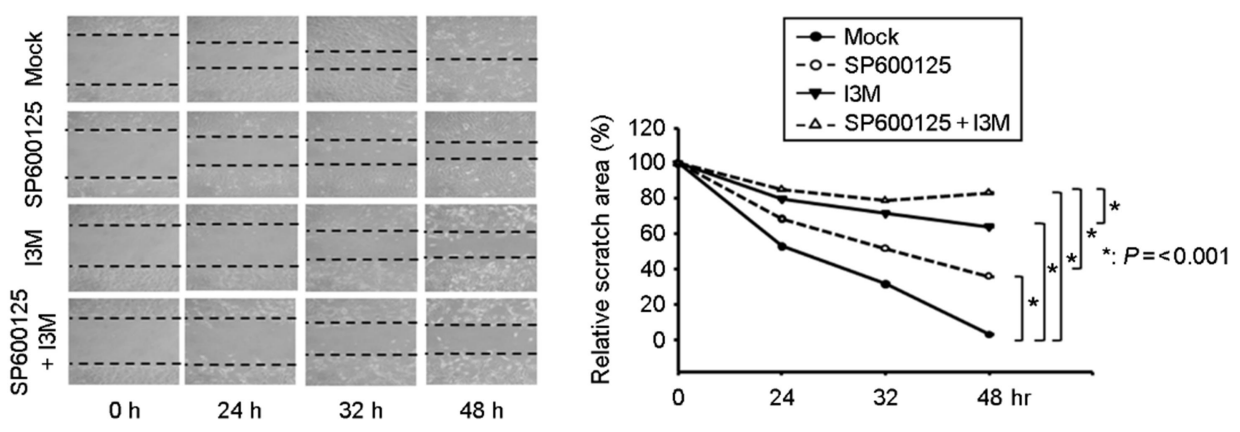

Fig. 4. Inhibition of JNK1 negatively regulates cancer cell growth. (A-C) MDA-MB 231 cells were treated for various time periods with DMSO, SP600125 $(20 \mu \mathrm{M})$, or I3M $(10 \mu \mathrm{M})$. (A) Cell viability was analyzed with the MTT assay. (B) Cell migration was analyzed with scratched wound healing assay. The data were quantified by measuring scratch area intensity using the ImageJ software. (C) Cell proliferation was analyzed with a colony forming assay. Cells were stained with crystal violet. Data represent the mean \pm standard deviation (SD) values of triplicates $(* P \leq 0.001)$. A-C All data were obtained from three independent experiments. 


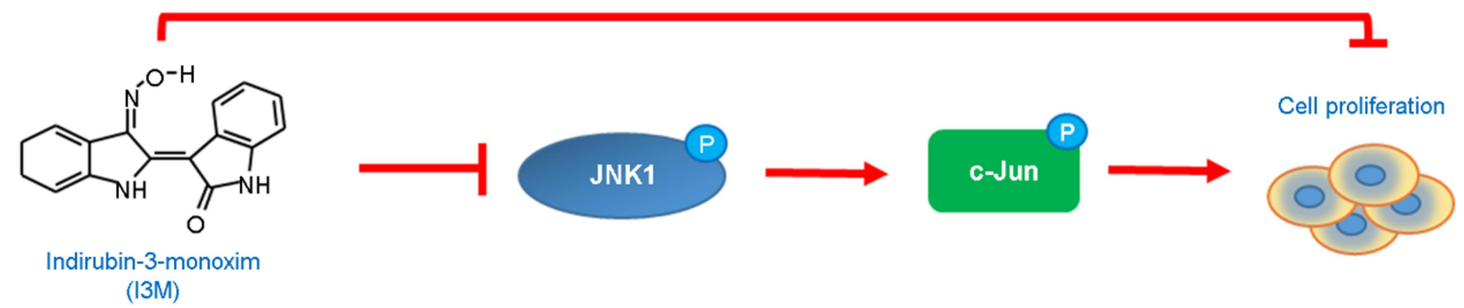

Fig. 5. Model for the role of $\mathbf{I 3 M}$ in the regulation of cancer proliferation. I3M directly inhibits JNK1 activity. I3M-reduced JNK1 activity decreases c-Jun phosphorylation. Decreased c-Jun phosphorylation inhibits cell proliferation.

Fig. 4B, the combination of SP600125 and I3M significantly decreased the migration distance, compared with either SP600125 or I3M. We also observed significant inhibition of colony formation ability in the cells treated with a combination of SP600125 and I3M (Fig. 4C). Cell growth, scratch wound healing, and colony forming ability were markedly blocked with the combination treatment than with the control or either SP600125 or I3M individually.

\section{DISCUSSION}

In a previous study, Xie et al. showed that I3M inhibits recombinant active JNK activity in vitro (Xie et al., 2004). The JNK signaling is mediated in the pathogenesis of various conditions such as ischemic stroke, Parkinson's disease (PD), as well as tauopathies, including Alzheimer's disease (AD) (Bode and Dong, 2007; Seki et al., 2012; Zeke et al., 2016; Hammouda et al., 2020). Additionally, the JNK pathway has important functions in both cancer cell survival and cell death processes (Kukekov et al., 2006). Therefore, it is unsurprising that JNK signaling is a key target for drug development. In most JNK function studies have used pharmacological inhibition of the signaling pathway by SP600125. However, SP600125 has been reported to inhibit 13 other protein kinases, including AMPK, CDK2, and SGK, as well (Bain et al., 2003).

Previous studies have revealed that the primary function of I3M is the inhibition of CDKs, which are important mediators of cell cycle progression, and GSK-3 $\beta$ which is mediated in neurodegenerative disorders. I3M has a broad spectrum of anti-tumorigenic activities in various kinds of human cancer cells (Schwaiberger et al., 2010). The main anticancer mechanism of I3M has been proposed to be the inhibition of CDKs (Hoessel et al., 1999; Leclerc et al., 2001) and GSK-3 $\beta$ (Bain et al., 2003). Lo et al. identified that I3M inhibits survivin expression, which is important mediator of oral cell survival (Lo and Chang, 2013). However, the specific mechanism of I3M anticancer function is still unknown. Of note, the unexpected mechanism by which I3M could inhibit JNK activity has recently been highlighted in cerebellar granule neurons (Xie et al., 2004).

Previous reports determined that as amount of phosphoJNK expression increase, tumor node metastasis (TNM) stage also increase and that phospho-JNK expression is correlated with positivity expression for CK5/6, basal-like, EGFR, and triple-negative phenotype of breast cancer (Wang et al., 2010). Based on previous study, activated JNK may be a key regulator for cancer therapy. Several kinds of JNK signaling inhibitors have been developed; however, factors such as substrate specificity and potential side effects pose limitations to their use.

In this studies, we identified the inhibition of JNK1 pathway by indirubin derivatives (Fig. 2). We also identified that I3M caused potent JNK1 inhibition activity (Fig. 3). Our results showed that phosphorylation of c-Jun was decreased by I3M. To determine the role of I3M in inhibiting JNK kinase activity in breast cancer, we examined its effect on breast cancer cell growth. As expected, breast cancer cell growth was inhibited in treated cells with either SP600125 or I3M (Fig. 4A). Similar results were acquired with the colony forming assay and scratched wound healing assay (Fig. 4B, C). Cell growth, colony forming abilities, and scratch wound healing were significantly inhibited in response to the combination treatment than to the control or 
either SP600125 or I3M alone. Our data strongly suggest that the JNK inhibitor I3M prevents breast cancer cell growth. It has been reported that SP600125 inhibits MCF-7 cell proliferation and cell cycle progression. Our data similarly support a role for JNK signaling inhibition by SP600125 in MCF-7 cell proliferation and cell cycle progression (Wood et al., 2018). These findings provide evidence of another mechanism for I3M anticancer activity, in addition to inhibition of CDK and GSK3 $\beta$.

In conclusion, our study found I3M to involve a key role in cancer cell proliferation through inhibiting JNK1 activity. Therefore, I3M, which inhibits JNK activity, could be a potential target for cancer therapy (Fig. 5).

\section{Abbreviations}

AP-1; activator protein-1, ATF; activating transcription factor, ER; estrogen receptor, EGFR2; epidermal growth factor receptor 2, I3M; indirubin-3-monoxime, JNK; c-Jun N-terminal kinase, MAF; musculoaponeurotic fibrosarcoma, PR; progesterone receptor, TNBC; triple negative breast cancer, TNM; Tumor-node-metastasis.

\section{ACKNOWLEDGEMENT}

This work was supported by the National Research Foundation of Korea (NRF) funded by the Korea government (MSIT) (No. NRF-2019R1A2C1007197). This study was financially supported by Chonnam National University (Grant number: 2016-2753). We would like to thank Editage (www.editage.co.kr) for English language editing.

\section{CONFLICT OF INTEREST}

The authors declare that they have no conflict of interest.

\section{REFERENCES}

Bain J, McLauchlan H, Elliott M, Cohen P. The specificities of protein kinase inhibitors: An update. Biochem J. 2003. 371: 199-204.

Bode AM, Dong Z. The functional contrariety of jnk. Mol Carcinog. 2007. 46: 591-598.

Bogoyevitch MA, Kobe B. Uses for jnk: The many and varied substrates of the c-jun n-terminal kinases. Microbiol Mol Biol Rev. 2006. 70: 1061-1095.
Cargnello M, Roux PP. Activation and function of the mapks and their substrates, the mapk-activated protein kinases. Microbiol Mol Biol Rev. 2011. 75: 50-83.

Guan QH, Pei DS, Zhang QG, Hao ZB, Xu TL, Zhang GY. The neuroprotective action of SP600125, a new inhibitor of jnk, on transient brain ischemia/reperfusion-induced neuronal death in rat hippocampal cal via nuclear and non-nuclear pathways. Brain Res. 2005. 1035: 51-59.

Hammouda MB, Ford AE, Liu Y, Zhang JY. The jnk signaling pathway in inflammatory skin disorders and cancer. Cells. 2020. 9.

Hoessel R, Leclerc S, Endicott JA, Nobel ME, Lawrie A, Tunnah P, Leost M, Damiens E, Marie D, Marko D, Niederberger E, Tang W, Eisenbrand G, Meijer L. Indirubin, the active constituent of a chinese antileukaemia medicine, inhibits cyclindependent kinases. Nat Cell Biol. 1999. 1: 60-67.

Hui L, Pei DS, Zhang QG, Guan QH, Zhang GY. The neuroprotection of insulin on ischemic brain injury in rat hippocampus through negative regulation of jnk signaling pathway by pi3k /akt activation. Brain Res. 2005. 1052: 1-9.

Insua-Rodriguez J, Pein M, Hongu T, Meier J, Descot A, Lowy CM, De Braekeleer E, Sinn HP, Spaich S, Sutterlin M, Schneeweiss A, Oskarsson T. Stress signaling in breast cancer cells induces matrix components that promote chemoresistant metastasis. EMBO Mol Med. 2018. 10.

Kukekov NV, Xu Z, Greene LA. Direct interaction of the molecular scaffolds posh and jip is required for apoptotic activation of jnks. J Biol Chem. 2006. 281: 15517-15524.

Leclerc S, Garnier M, Hoessel R, Marko D, Bibb JA, Snyder GL, Greengard P, Biernat J, Wu YZ, Mandelkow EM, Eisenbrand G, Meijer L. Indirubins inhibit glycogen synthase kinase-3 beta and cdk5/p25, two protein kinases involved in abnormal tau phosphorylation in alzheimer's disease. A property common to most cyclin-dependent kinase inhibitors? J Biol Chem. 2001 276: 251-260.

Lee MJ, Kim MY, Mo JS, Ann EJ, Seo MS, Hong JA, Kim YC, Park HS. Indirubin-3'-monoxime, a derivative of a chinese anti-leukemia medicine, inhibits notch1 signaling. Cancer Lett. 2008. 265: 215-225.

Lehmann BD, Bauer JA, Chen X, Sanders ME, Chakravarthy AB, Shyr Y, Pietenpol JA. Identification of human triple-negative breast cancer subtypes and preclinical models for selection of targeted therapies. J Clin Invest. 2011. 121: 2750-2767.

Liao XM, Leung KN. Indirubin-3'-oxime induces mitochondrial dysfunction and triggers growth inhibition and cell cycle arrest 
in human neuroblastoma cells. Oncol Rep. 2013. 29: 371-379.

Lin A, Dibling B. The true face of jnk activation in apoptosis. Aging Cell. 2002. 1: 112-116.

Lo WY, Chang NW. An indirubin derivative, indirubin-3'-monoxime suppresses oral cancer tumorigenesis through the downregulation of survivin. PLoS One. 2013. 8: e70198.

Marko D, Schatzle S, Friedel A, Genzlinger A, Zankl H, Meijer L, Eisenbrand G. Inhibition of cyclin-dependent kinase 1 (cdk1) by indirubin derivatives in human tumour cells. Br J Cancer. 2001. 84: 283-289.

Mehan S, Meena H, Sharma D, Sankhla R. Jnk: A stress-activated protein kinase therapeutic strategies and involvement in alzheimer's and various neurodegenerative abnormalities. J Mol Neurosci. 2011. 43: 376-390.

Moon MJ, Lee SK, Lee JW, Song WK, Kim SW, Kim JI, Cho C, Choi SJ, Kim YC. Synthesis and structure-activity relationships of novel indirubin derivatives as potent anti-proliferative agents with cdk2 inhibitory activities. Bioorg Med Chem. 2006. 14: 237-246.

Nam S, Buettner R, Turkson J, Kim D, Cheng JQ, Muehlbeyer S, Hippe F, Vatter S, Merz KH, Eisenbrand G, Jove R. Indirubin derivatives inhibit stat3 signaling and induce apoptosis in human cancer cells. Proc Natl Acad Sci U S A. 2005. 102: 5998-6003.

Nielsen TO, Hsu FD, Jensen K, Cheang M, Karaca G, Hu Z, Hernandez-Boussard T, Livasy C, Cowan D, Dressler L, Akslen LA, Ragaz J, Gown AM, Gilks CB, van de Rijn M, Perou CM. Immunohistochemical and clinical characterization of the basal-like subtype of invasive breast carcinoma. Clin Cancer Res. 2004. 10: 5367-5374.

Park JG, Aziz N, Cho JY. Mkk7, the essential regulator of jnk signaling involved in cancer cell survival: A newly emerging anticancer therapeutic target. Ther Adv Med Oncol. 2019. 11: 1758835919875574.

Schwaiberger AV, Heiss EH, Cabaravdic M, Oberan T, Zaujec J, Schachner D, Uhrin P, Atanasov AG, Breuss JM, Binder BR, Dirsch VM. Indirubin-3'-monoxime blocks vascular smooth muscle cell proliferation by inhibition of signal transducer and activator of transcription 3 signaling and reduces neointima formation in vivo. Arterioscler Thromb Vasc Biol. 2010. 30: 2475-2481.

Seki E, Brenner DA, Karin M. A liver full of jnk: Signaling in regulation of cell function and disease pathogenesis, and clinical approaches. Gastroenterology. 2012. 143: 307-320.

Verrecchia F, Tacheau C, Wagner EF, Mauviel A. A central role for the jnk pathway in mediating the antagonistic activity of pro-inflammatory cytokines against transforming growth factorbeta-driven smad3/4-specific gene expression. J Biol Chem. 2003. 278: 1585-1593.

Wang X, Chao L, Li X, Ma G, Chen L, Zang Y, Zhou G. Elevated expression of phosphorylated c-jun nh2-terminal kinase in basal-like and "triple-negative" breast cancers. Hum Pathol. 2010. 41: 401-406.

Wood RA, Barbour MJ, Gould GW, Cunningham MR, Plevin RJ. Conflicting evidence for the role of jnk as a target in breast cancer cell proliferation: Comparisons between pharmacological inhibition and selective shrna knockdown approaches. Pharmacol Res Perspect. 2018. 6.

Xiao Z, Hao Y, Liu B, Qian L. Indirubin and meisoindigo in the treatment of chronic myelogenous leukemia in china. Leuk Lymphoma. 2002. 43: 1763-1768.

Xie Y, Liu Y, Ma C, Yuan Z, Wang W, Zhu Z, Gao G, Liu X, Yuan H, Chen R, Huang S, Wang X, Zhu X, Wang X, Mao Z, Li M. Indirubin-3'-oxime inhibits c-jun nh2-terminal kinase: Anti-apoptotic effect in cerebellar granule neurons. Neurosci Lett. 2004. 367: 355-359.

Zeke A, Misheva M, Remenyi A, Bogoyevitch MA. Jnk signaling: Regulation and functions based on complex protein-protein partnerships. Microbiol Mol Biol Rev. 2016. 80: 793-835.

Zhao HF, Wang J, Tony To SS. The phosphatidylinositol 3-kinase/ akt and c-jun n-terminal kinase signaling in cancer: Alliance or contradiction? (review). Int J Oncol. 2015. 47: 429-436.

Zhen Y, Sorensen V, Jin Y, Suo Z, Wiedlocha A. Indirubin-3'monoxime inhibits autophosphorylation of fgfr1 and stimulates erk1/2 activity via p38 mapk. Oncogene. 2007. 26: 63726385 .

https://doi.org/10.15616/BSL.2021.27.3.134

Cite this article as: Kim MY, Jo EH, Kim YC, Park HS. Indirubin-3-monoxime Prevents Tumorigenesis in Breast Cancer through Inhibition of JNK1 Activity. Biomedical Science Letters. 2021. 27: 134-141. 